\title{
Pure extra-thoracic sarcoidosis: about 24 cases
}

\author{
DONIA CHEBBI ${ }^{1}$, SAMEH MARZOUK $^{1}$, MOUNA SNOUSSI ${ }^{1}$, NESSRINE REGAIEG $^{1}$, NAWREZ GOUIAA $^{2}$, \\ RAIDA BEN SALAH ${ }^{1}$, CHIFA DAMAK ${ }^{1}$, FATEN FRIKHA ${ }^{1}$, TAHIA BOUDAWARA ${ }^{2}$, ZOUHIR BAHLOUL ${ }^{1}$
}

\author{
${ }^{1}$ Department of Internal Medicine, Hedi Chaker University Hospital, Sfax, Tunisia \\ ${ }^{2}$ Department of Histology, Habib Bourguiba University Hospital, Sfax, Tunisia
}

\begin{abstract}
Introduction. Pure extra-thoracic sarcoidosis is rare and poorly characterized in the literature. Herein we present features of pure extra-thoracic sarcoidosis, in comparison with sarcoidosis with intra-thoracic involvement, in a population from the south of Tunisia.

Methods. Retrospective, descriptive and comparative study of the patients presenting systemic sarcoidosis and attending the Department of Internal Medicine at the Hedi Chaker University Hospital, Sfax, Tunisia, for 21 years, from January 1996 to December 2016.

Results. Twenty-four patients presented pure extra-thoracic sarcoidosis $(30 \%$ of the cases of systemic sarcoidosis). There was a female predominance (79\%). The mean age was 50 years. The main features were polyadenopathies (10 patients: $41.7 \%$ ), cutaneous involvement (10 patients: $41.6 \%$ ), inflammatory polyarthralgia ( 8 cases: $33.3 \%$ ), general symptoms (6 patients: $25 \%$ ), uveitis (6 cases: $25 \%$ ), cholestasis (3 cases) and kidney involvement (2 cases). Lymphopenia, hypercalcemia, and hypercalciuria were observed each one in $12.5 \%$ of the cases, and high angiotensin converting enzyme (ACE) level in $38.5 \%$ of the cases. The histological proof was required in all the patients. Statistically significant associations identified were mainly hepatic involvement with general symptoms $(p=0.035)$, peripheral lymphadenopathies $(\mathrm{p}=0.035)$ and kidney damage $(\mathrm{p}=0.022)$, and cutaneous involvement with articular manifestations $(\mathrm{p}=0.032)$. Systemic corticosteroids were used in half of the cases, with a good outcome in 21 cases, and recurrence in two cases. One patient was lost to follow up. The comparison to the form with mediastino-pulmonary involvement showed less lymphadenopathies $(\mathrm{p}=0.001)$, less lymphopenia ( $\mathrm{p}=0.006$ ), and less frequent use of corticosteroids ( $\mathrm{p}=0.044)$.

Conclusion. Our series was characterized by the frequency of the pure extra-thoracic form and the diversity of the systemic manifestations.
\end{abstract}

Key words: sarcoidosis, uveitis, granuloma, glucocorticoids, lymphadenopathy, Tunisia.

\section{INTRODUCTION}

Sarcoidosis still arouses interest among clinicians and scientists since its first description by Jonathan Hutchinson in 1869 [1]. The etiology of this disease is still unknown, its evolution unpredictable, and its treatment not well codified. Few studies have been conducted on north Africans and in particular Tunisians. Sarcoidosis is a systemic disease characterized by the formation of non-necrotizing epithelioid cell granulomas in one or many organs. It affects adults with female predilection. Pulmonary manifestations affect the vast majority of the patients [2], but many other organs are often affected as well, such as eyes and skin $[3,4]$. There are three main presentations of sarcoidosis: pure intra-thoracic sarcoidosis (40$50 \%$ of cases), intra and extra thoracic sarcoidosis
(30-50\% of cases) and pure extra thoracic sarcoidosis (5-20\% of cases). The latter form is rare, and often poses a problem of positive diagnosis. Several treatment alternatives are proposed in sarcoidosis, depending on the organ affected, the severity of the affection and the personal experience of the clinician. However, corticosteroids remain the first line treatments [5].

In the current report, we present the main epidemiological, clinical, biological and histological features of pure extra-thoracic sarcoidosis in a population from the south of Tunisia. In addition, we study the correlation between these features, and their impact on the evolution of the disease. We also compared the different manifestations of the pure extra-thoracic 
sarcoidosis and the sarcoidosis with intra and extra-thoracic involvement.

\section{MATERIAL AND METHODS}

We included in this study the patients presenting systemic sarcoidosis and attending the Department of Internal Medicine at the Hedi Chaker University Hospital, Sfax, Tunisia, for 21 years, from January 1996 to December 2016. The diagnosis of sarcoidosis required the presence of suggestive clinical symptoms, a cluster of paraclinical arguments including the presence of a nonnecrotizing epithelioid cell granuloma, and the exclusion of other etiologies of granulomas, in particular tuberculosis.

The patients were seen every three to six months. At each visit, the patients' history was reviewed in addition to physical examination, laboratory tests, and other explorations depending on the affected organs.

The following data were collected: age at diagnosis, gender, clinical signs (pulmonary and extra-pulmonary signs), biological features (complete blood count, calcemia, 24 hours calciuria, liver enzymes, C-reactive protein (CRP), erythrocyte sedimentation rate (ESR), Serum protein electrophoresis (SPEP) and creatinine concentration).

Biopsies were performed on all patients according to the clinical and radiological orientation.

A descriptive study was performed to analyze the frequency of the clinical manifestations, biological results, histological findings, and to specify treatments used. A comparative analysis was also conducted to find correlations between the different features and to compare the two groups: the group of pure extra-thoracic sarcoidosis and the group of sarcoidosis with intra-thoracic involvement. Qualitative differences were analyzed with the chisquare test and Fisher's exact test. The significance level $(\leq 0.05)$ was used for testing the statistical difference of the hypotheses. Statistical analysis was conducted using IBM SPSS Statistics for Windows v20 (IBM Corp., Armonk, NY).

\section{RESULTS}

\section{Description of groups}

Within a cohort of 80 sarcoidosis patients, we identified two groups: a group of pure extrathoracic sarcoidosis (24 patients: $30 \%$ of the cases) and a group of patients presenting intrathoracic sarcoidosis associated or not with extra- thoracic features (56 cases: 70\%). Our present work focuses on the pure extra-thoracic group, which will be later compared to the second one.

\section{Epidemiological characteristics}

Among 24 patients presenting pure extrathoracic sarcoidosis, there were 5 men $(21 \%)$ and 19 women (79\%). The mean age was 50 years, with extremes of 15 and 79 years.

The distribution of the patients by age showed two peaks of frequency: between 40 and 49 years, and between 60 and 69 years.

\section{Systemic manifestations}

We observed in our series polyadenopathies in 10 patients $(41.7 \%)$, peripheral in 6 cases and abdominal in 5 cases diagnosed by abdominal ultrasound or abdominal CT scan. Cutaneous involvement concerned 10 patients (41.6\%): eight cases of erythema nodosum and four cases of specific skin lesions with granulomatosis on skin biopsy (lupus pernio ( 1 case), ulcerated lesion in the thigh (1 case) and purple plaques in two cases). Eight patients presented inflammatory polyarthralgia (33.3\%) with arthritis in 5 cases. General symptoms (fever, asthenia and/or weight loss) were observed in 6 patients $(25 \%)$. Six patients had uveitis $(25 \%)$. It was a panuveitis in 5 patients and an anterior uveitis in one patient, granulomatous in three cases. Uveitis recurred in two cases (intermediate uveitis). It was complicated by retinal vasculitis and macular edema in two cases. Hepatomegaly was objectified in 3 patients. Cholestasis was noted in 3 cases, associated with cytolysis in one case. Two patients had kidney involvement. Both of them had renal failure with a median creatinine level of $160 \mathrm{umol} / \mathrm{L}$. It was functional in the first case, due to hypercalcemia. In the second case, the renal failure was associated with aseptic leukocyturia without neither proteinuria nor hypercalcemia or hypercalciuria, with two kidneys of normal size on ultrasound. It was most likely due to a granulomatous interstitial nephritis infiltration. Renal puncture biopsy was indicated but was not performed due to the deterioration of the general condition. Ear, nose and throat (ENT) damage concerned one patient who presented a nasal obstruction and hypertrophy of the nasal septum with cartilage inflammation. Gingival hyperplasia was observed in two cases and parotid hypertrophy in one case. Bone marrow involvement was diagnosed in one case. The main biological markers were leucopenia, lymphopenia, hypercalcemia, and hypercalciuria each one in $12.5 \%$ of the cases, polyclonal hypergammaglobulinemia in $47.4 \%$ and hight ACE level in 38,5\% of the cases (Table 1). 
Table 1

Comparison between manifestations in sarcoidosis with and without thoracic involvement

\begin{tabular}{|l|l|l|l|}
\hline & $\begin{array}{l}\text { Sarcoidosis with thoracic } \\
\text { involvement n(\%) }\end{array}$ & $\begin{array}{l}\text { Pure extra-thoracic } \\
\text { sarcoidosis n(\%) }\end{array}$ & $P$ \\
\hline Patients number & 56 & 24 & \\
\hline Lymph nodes & $45(80.4)$ & $10(41.7)$ & 0.001 \\
\hline General signs & $19(33.5)$ & $6(25)$ & 0.43 \\
\hline Erythema nodosum & $8(14.3)$ & $8(33.3)$ & 0.51 \\
\hline Uveitis & $8(14.3)$ & $6(25)$ & 0.24 \\
\hline Osteo-articular & $13(23.2)$ & $8(33.3)$ & 0.34 \\
\hline Hepatic & $18(32)$ & $4(16.7)$ & 0.15 \\
\hline ENT & $7(12.5)$ & $1(4.2)$ & 0.42 \\
\hline Hypercalcemia & $4(7.4)$ & $3(12.5)$ & 0.46 \\
\hline Hypercalciuria & $6(16.2)$ & $2(12.5)$ & 0.72 \\
\hline Inflammatory biological syndrom & $20(37)$ & $8(34.8)$ & 0.85 \\
\hline Polyclonal hypergamma & $29(63)$ & $9(47.4)$ & 0.24 \\
\hline High ACE & $23(67.6)$ & $5(38.5)$ & 0.068 \\
\hline Lymphopenia & $25(44.6)$ & $3(12.5)$ & $\mathbf{0 . 0 0 6}$ \\
\hline Corticotherapy & $41(73.2)$ & $12(50)$ & $\mathbf{0 . 0 4 4}$ \\
\hline Recurrence & $4(8.2)$ & $2(8.7)$ & 0.93 \\
\hline
\end{tabular}

PS. The percentages are calculated taking into account the number of tests performed

ENT ear, nose and throat, ACE angiotensine converting enzyme

\section{Histologic confirmation}

The histological proof was required in all our patients. A total of 42 biopsies were performed, i.e. 1.75 biopsies/patient, in 10 different sites. Biopsies were positive in 28 cases $(66.6 \%)$.

The different biopsy sites and their effectiveness (number of positive biopsies/number of biopsies performed) are shown in Table 2.

\section{Table 2}

Biopsy sites and their effectiveness

\begin{tabular}{|l|l|l|l|}
\hline Site of the biopsy & Number of patients & Positive biopsies & Effectiveness (\%) \\
\hline Superficial lymph nodes & 6 & 6 & 100 \\
\hline Accessory salivary glands & 22 & 14 & 63 \\
\hline Cutaneous & 7 & 5 & 71 \\
\hline Hepatic & 2 & 0 & 0 \\
\hline Bone marrow biopsy & 1 & 1 & 100 \\
\hline
\end{tabular}

\section{Clinico-biological correlations}

Many statistically significant associations were identified in our series. Hepatic involvement was associated to general symptoms $(\mathrm{p}=0.035)$, peripheral lymphadenopathies $(\mathrm{p}=0.035)$ and kidneys damage $(\mathrm{p}=0.022)$. Lupus pernio was associated with ENT manifestations $(\mathrm{p}=0.042)$. General signs were correlated to renal involvement $(\mathrm{p}=0.054)$ and to biological inflammatory syndrome $(\mathrm{p}=0.033)$. Cutaneous involvement was associated with articular manifestations $(\mathrm{p}=0.032)$ and inflammatory biological syndrome $(\mathrm{p}=0.023)$. Polyclonal hypergammaglobulinemia was associated with hepatomegaly $(\mathrm{p}=0.033)$ and finally the elevation of ACE was associated with hepatomegaly (0.032) and splenic involvement ( $\mathrm{p}=0.035)$.

\section{Diagnosis}

The diagnosis of sarcoidosis was made in our series in three conditions:

- Involvement of at least 2 organs with a single positive biopsy (18 cases: $75 \%$ )

- Involvement of at least 2 organs with 2 positive biopsies ( 4 cases)

- Single organ involvement with a single positive biopsy in 2 patients.

These two patients presented biological manifestations of sarcoidosis: lymphopenia, hypercalcemia, and hypercalciuria. 


\section{Treatment}

Therapeutic abstention was recommended in 4 patients $(16.6 \%)$ presenting isolated lymphadenopathies. Non-steroidal anti-inflammatory drugs alone were prescribed in 5 patients having arthritis (20.8\%). We used systemic corticotherapy in 12 patients (50\% of cases). Oral prednisone $1 \mathrm{mg} / \mathrm{kg} / \mathrm{d}$ was indicated in the presence of renal failure ( 2 cases), hypercalcemia (1 case), bone marrow involvement (1 case), multisystemic damage including general signs and hypercalcemia (1 case), and panuveitis (1 case). This dose was initiated by three pulses of $1 \mathrm{~g} / \mathrm{d}$ of methylprednisolone in four patients presenting recurrent severe panuveitis with an important decline of visual acuity, complicated in two patients by retinal vasculitis and macular edema. The two cases of gingival hyperplasia were treated with prednisone $0.5 \mathrm{mg} / \mathrm{kg} / \mathrm{d}$, followed by gingivectomy in one case. Corticosteroid eye drops were used in the case of anterior uveitis. One patient with a specific cutaneous manifestation received anti-malarial drugs alone.

\section{Evolution and prognosis}

Among our 24 patients, only one was lost to follow-up within 3 months.

Recovery was obtained in ten patients (41.7\%). Five patients (20.8\%) experienced total regression of the symptoms. They were followed for less than three years, which didn't allow us to define recovery. Six patients experienced improvement of the disease with some sequelae. Recurrence was observed in two cases $(8.7 \%)$ (recurrent granulomatous panuveitis).

The recovery was statistically correlated with the cutaneous involvement $(p=0.017)$, the inflammatory arthralgia $(\mathrm{p}=0.019)$ and the inflammatory biological syndrome $(\mathrm{p}=0.01)$.

\section{Comparison between pure extra-pulmonary sarcoidosis and sarcoidosis with mediastino- pulmonary involvement}

Compared to forms with mediastino-pulmonary involvement, pure extra-thoracic involvement was associated with lower prevalence of lymphadenopathies $(\mathrm{p}=0.001)$, lower prevalence of lymphopenia $(\mathrm{p}=0.006)$ and a less frequent use of corticosteroids $(\mathrm{p}=0.044)$. The comparison of the other manifestations between the forms with and without lung involvement showed no significant difference (Table 1).

\section{DISCUSSION}

Extra-medastino-pulmonary manifestations are frequent during sarcoidosis. They are often associated with intrathoracic involvement [6]. Purely extra-thoracic sarcoidosis is rare. It accounts for 5 to $20 \%$ of cases [7].

Our series is characterized by the high frequency of this form of sarcoidosis in comparison to other series from the world (Table 3). This may be explained by the recruitment bias in an internal medicine department.

It is more frequent in women, which is the case in our study (79\%), and in the African-American population [6].

This presentation of the disease often causes diagnostic difficulties, leading to delays in management [8]. Pulmonary involvement may manifest itself subsequently during follow-up. It may also be subclinical, revealed by more aggressive investigation at initial diagnosis by bronchoscopy and bronchoalveolar lavage (BAL) [9].

Despite its multisystemic nature, most clinicians accept the diagnosis of sarcoidosis in the presence of isolated mediastino-pulmonary involvement confirmed by biopsy, after elimination of other causes of pulmonary granulomatosis. In pure extra-thoracic forms, the presence of a granuloma in a single organ does not lead to the diagnosis of this disease, since there are idiopathic granulomatosis affecting a single organ (idiopathic granulomatous hepatitis, idiopathic granulomatous uveitis, etc.). In these cases, at least two organs must be affected in order to diagnose sarcoidosis. This does not imply that both organs must be biopsied [10,11]. In fact, clinical criteria have been established to consider an organ as affected by sarcoidosis without biopsy. These are ACCESS instrument (1991) [12] and WASOG instrument (2014)[11]. In our study, the diagnosis of sarcoidosis was made when at least two organs were affected with a single positive biopsy (18 cases), when at least two organs were affected with two positive biopsies (4 cases) and when only one organ was affected with a single positive biopsy in two patients.

Clinico-biological correlations were found in our series, some of which have been reported in the literature, such as association between hepatic involvement and general signs, lupus pernio and ENT damage, and cutaneous and articular manifestations $[13,14]$. 
Table 3

Incidence of pure extra-thoracic sarcoidosis in our series and in the world

\begin{tabular}{|l|l|l|l|}
\hline Series & Country & Total number & $\begin{array}{l}\text { \% pure extra-thoracic } \\
\text { sarcoidosis }\end{array}$ \\
\hline ACCESS (2001) (12) & USA & 736 & $2 \%$ \\
\hline Chappell (2001) (20) & United Kingdom & 212 & $9 \%$ \\
\hline Morimoto (2008) (21) & Japan & 1,027 & $14 \%$ \\
\hline TTS (2011) (22) & Turkey & 293 & $1 \%$ \\
\hline Our series & Tunisia & $\mathbf{8 0}$ & $\mathbf{3 0 \%}$ \\
\hline
\end{tabular}

New correlations specific to our series were also raised: hepatic involvement with peripheral lymphadenopathies and kidneys damage, general signs with renal involvement and biological inflammatory syndrome, cutaneous involvement with inflammatory biological syndrome, polyclonal hypergammaglobulinemia with hepatomegaly, and finally the elevation of ACE with hepatomegaly and splenic involvement.

Although there is no well-validated therapeutic protocol, corticosteroid therapy remains a cornerstone of sarcoidosis treatment. The recommended induction dose is $0.5 \mathrm{mg} / \mathrm{kg} /$ day of equivalent prednisone, and reaches $1 \mathrm{mg} / \mathrm{kg} /$ day in case of severe impairment. Solumedrol boluses are required in threatening damages with a necessity of rapid results, such as optic neuritis or severe central nervous system involvement [15].

When a good response is obtained, progressive decrease should be started until the minimal effective dose of corticoids (5 to $10 \mathrm{mg}$ /day of prednisone).

Generally, the treatment must be maintained for more than 12 months. Nevertheless, the duration should be adapted on a case-by-case basis [16-18]. Corticosteroids were used in half of the patients in our series.
Because of its large clinical polymorphism, the clinical course of sarcoidosis is difficult to predict. Half of the affected subjects recover spontaneously after 2 years. Recovery is still possible within 5 years, but much less likely afterwards [17,19]. Almost half of our patients experienced recovery. Some factors were correlated to good prognosis in our study: cutaneous involvement, inflammatory arthralgia and inflammatory biological syndrome.

\section{CONCLUSION}

Despite the mediastino-pulmonary affinity of sarcoidosis, pure extra-thoracic forms have been described, often posing problems of positive diagnosis. A positive diagnosis in this case often requires the presence of involvement of at least two organs, at least one of which is histologically proven, with the elimination of differential diagnoses.

Through this study, we described the different manifestations of pure extra-thoracic sarcoidosis, treatment and prognosis in a population from the south of Tunisia. Correlations between the different features were also reported. Our series was characterized by the frequency of the pure extrathoracic form and the diversity of the systemic manifestations.

Introducere. Sarcoidoza extratoracică este rară şi puțin descrisă în literatură. Sunt prezentate caracteristicile unor pacienți cu sarcoidoză extratoracică comparativ cu pacienți cu sarcoidoză toracică în cadrul unei serii de pacienți din sudul Tunisiei.

Metode. Au fost analizate retrospectiv fișele pacienților cu sarcoidoză sistemică din spitalul Hedi Chaker University Hospital, Sfax, Tunisia, pe o perioadă de 21 de ani din ianuarie 1996 până în decembrie 2016.

Rezultate. 24 de pacienți au avut sarcoidoză pură extratoracică $(30 \%$ din cazurile totale de sarcoidoză). $79 \%$ au fost femei. Vârsta medie a fost de 50 de ani. Caracteristicile principale au fost poliadenopatia (10 pacienți, 4,7\%), afectarea cutanată (10 pacienți, 41,7\%), poliartralgia inflamatorie (8 pacienți $33,3 \%$ din 
cazuri), simptome generale (6 pacienți, 25\%), uveită (6 pacienți, 25\%), colestază (3 pacienți) și afectare renală (2 pacienți). Limfopenia, hipercalcemia și hipercalciuria s-au observat la 12,5\% dintre pacienți. 38,5\% dintre aceștia Au avut niveluri crescute ale ACE. Confirmarea prin biopsie a fost necesară. Afectarea hepatică s-a asociat cu simptomele generale, limfadenopatia, afectarea renală, afectarea cutanată și afectarea articulară. Corticoterapia a fost utilizată la jumătate dintre pacienți. 21 dintre pacienți au avut un prognostic bun. 2 pacienți au avut recurență.

Concluzii. Seria de pacienți cu sarcoidoză prezentată a avut o frecvență crescută a formei extratoracice.

Correspondence to: Donia Chebbi, M.D, Hedi Chaker University Hospital, Sfax, Tunisia, E-mail: doniachebba@gmail.com,

Telephone: +21622308574

Conflict of interest disclosure: All authors declare no conflict of interest.

\section{REFERENCES}

1. SPAGNOLO P. Sarcoidosis: a Critical Review of History and Milestones. Clin Rev Allergy Immunol. 2015;49(1):1-5.

2. FINGERLIN TE., HAMZEH N., MAIER LA. Genetics of Sarcoidosis. Clin Chest Med. 2015;36(4):569-584.

3. SPAGNOLO P., ROSSI G., TRISOLINI R., SVERZELLATI N., BAUGHMAN RP., WELLS AU. Pulmonary sarcoidosis. The Lancet Respir Med. 2018;6(5):389-402.

4. CHEN ES., MOLLER DR. Etiologies of Sarcoidosis. Clin Rev Allergy Immunol. 2015;49(1):6-18.

5. BRITO-ZERON P., PEREZ-ALVAREZ R., PALLARES L., RETAMOZO S., BAUGHMAN RP., RAMOS-CASALSON M. Sarcoidosis: an update on current pharmacotherapy options and future directions. Expert Opinion on Pharmacotherapy. 2016;17(18):2431-2448.

6. IPPERSIEL V., POCHET JM., DONCKIER J. Granulomatose médullaire: une présentation rare de sarcoïdose?. Louv Med. 2009;128(2):79-84.

7. MOUTHON L., HANSLIK T., VILLARD J-F. Sarcoïdose. In: Médecine interne ECN, MED-LINE Editions, Paris, 2018. p. 261-77.

8. VALEYRE D., DUPERRON F. Sarcoïdose: Dépistage et gestion des atteintes extra-pulmonaires. Rev Mal Respir. 2006;23(6):757-758.

9. BART P., PRUVOT E., PRIOR J., WAEBER G. Sarcoüdose extrapulmonaire: entité méconnue? Rev Med Suisse. 2010;6:2056-2060.

10. JUDSON MA. Extrapulmonary Sarcoidosis. Semin Respir Crit Care Med. 2007;28:83-101.

11. JUDSON MA., BAUGHMAN RP. How many organs need to be involved to diagnose sarcoidosis? An unanswered question that, hopefully, will become irrelevant. Sarcoidosis Vasc Diffus Lung Dis. 2014;31(1):19-27.

12. BAUGHMAN RP., TEIRSTEIN AS., JUDSON MA., ROSSMAN MD., YEAGER JR H., BRESNITZ EA., et al. Clinical characteristics of patients in a case control study of sarcoidosis. Am J Respir Crit Care Med. 2001;164:1885-1889.

13. ELLOUMI H., MARZOUK S., TAHRI N., BAHLOUL Z., AZOUZ MM. Sarcoïdose et atteinte hépatique: Étude de 25 cas. Rev Med Interne. 2012;33(11):607-614.

14. JUDSON MA. The Clinical Features of Sarcoidosis: A Comprehensive Review. Clin Rev Allergy Immunol. 2015;49(1):63-78.

15. VALEYRE D., JENY F., NUNES H. Current Medical Therapy for Sarcoidosis. Semin Respir Crit Care Med. 2017;38:523-531.

16. HUNNINGHAKE GW. Statement on Sarcoidosis. Am J Respir Crit Care Med. 1999;160(3):736-755.

17. VALEYRE D., PRASSE A., NUNES H., UZUNHAN Y., BRILlET P., MULLER-QUERNHEIM J. Sarcoidosis. Seminar. 2013;383(9923):1155-1167.

18. ROCHAT TS., JANSSENS J-P., SOCCAL PM., ADLER D. Mise au point sur le traitement de la sarcoüdose. Rev Med Suisse. 2016;12:1966-1971.

19. PRASSE A., KATIC C., GERMANN M., BUCHWALD A., ZISSEL G., MULLER-QUERNHEIM J. Phenotyping sarcoidosis from a pulmonary perspective. Am J Respir Crit Care Med. 2008;177(3):330-336.

20. CHAPPEL A., CHEUNG W., HUTCHINGS H. Sarcoidosis: a long-term follow up study. Sarcoidosis Vasc Diffus Lung Dis. 2001;17(2):167-173.

21. MORIMOTO T., AZUMA A., ABE S., USUKI J., KUDOH S., SUGISAKI K. et al. Epidemiology of sarcoidosis in Japan. Eur Respir J. 2008;31(2):372-379.

22. OKUMUS G., MUSELliM B., CETINKAYA E., TURKER H., UZASLAN E., YENTURK E., et al. Extrapulmonary involvement in patients with sarcoidosis in Turkey. Respirology. 2011;16(3):446-50.

Received $7^{\text {th }}$ February 2021 